\title{
ECOLOGICAL STATUS AND PEOPLES' PERCEPTION OF MISTLETOES IN PANCHASE PROTECTED FOREST, CENTRAL NEPAL HIMALAYAS
}

\author{
Dipak Bohora, Mohan P. Devkota* \\ Department of Botany, Amrit Campus, Tribhuvan University, Kathmandu, Nepal \\ *Corresponding author: mohanpdevkota@gmail.com
}

(Received: February 30, 2020; Revised: May 3, 2020; Accepted: May 14, 2020)

\begin{abstract}
Realizing the importance of Panchase Protected Forest, an important corridor of the Chitwan-Annapurna Landscape (CHAL) area, the ecological status and peoples' perception of mistletoe was studied to supplement the information on mistletoes of Nepal Himalayas. Mistletoes were studied along the forest trails and data were collected within $10 \mathrm{~m}$ radius plots $20 \mathrm{~m}$ inside the trails to record the incidence of mistletoe occurrence and severity of infection during three field visits in 1917 and 1918. Fifty people were interviewed using a semi-structured questionnaire and Biodiversity Conservation Confidence Index was calculated to understand peoples' perceptions about mistletoes. A total of seven mistletoe species, six belonging to four genera in the family Loranthaceae, and a single genus in the family Viscaceae were documented from 27 host species belonging to 24 genera in 18 unrelated angiosperm host families. Loranthaceae mistletoes were more generalists having a wide host range while Viscaceae mistletoe showed a high degree of host specificity. The irregular and patchy distribution of mistletoe is governed by host availability, forest structure, and site mesoclimate. Knowledge regarding the importance and uses of mistletoes and its values in natural plant communities is limited to older generation people. Age groups, profession, and the mechanism of indigenous knowledge inheritance in the rural mountainous communities of the Panchase area are very poor and are eroding rapidly which is against promoting the indigenous knowledge system especially in the younger generation. More conservation initiatives are needed through the stakeholder involvement to protect the rich biodiversity of the area.
\end{abstract}

Keywords: Distribution, Diversity, Host range, Mistletoe, Nepal, Peoples’ perception.

\section{INTRODUCTION}

Mistletoes are a polyphyletic group of parasitic flowering plants and have been reported to infest a wide range of host plants around the globe (Kuijt, 1969). This group of highly specialized plants can exploit their host plants by a highly modified root system 'haustorium' and is strictly aerial in the habit. Due to their nutritional dependency on host plants they may be 'hemiparasite' e.g. leafy mistletoe extracting only water and nutrients from host tissues whereas, the 'holoparasites' are leafless and trap host phloem tissues. This kind of parasitic nutritional mode of life is believed to be one of the highly prosperous heterotrophic strategies in the flowering plants (Nickrent, 1997). Mistletoes belong to the sandalwood order Santalales and have evolved five times within the order representing 88 genera and 1589 species (Nickrent, 2011).

Although multiple infections by mistletoe on a single host may be energetically expensive (Mallams \& Mathiasen, 2010), there is a strong positive association between wildlife diversity and its functions as a keystone resource in some ecosystems (Watson, 2001). Apart from being an important source of food for birds, insects, and small mammals, mistletoes further support animal diversity by altering the structure of their hosts by providing microhabitats on host trees (Mathiasen et al., 2008) and by adding structure and complexity to forest habitats (Aukema, 2003).
Mistletoes occur in a wide variety of habitats ranging from tropical rain forests and mangroves to arid shrublands (Shaw et al., 2004), but most research on distribution patterns and dispersal have focused on semiarid habitats, with tropical and temperate regions being underrepresented in the mistletoe literature (Watson, 2001). They have been reported from tropical lowland forests to upper cool temperate forests of Nepal from a wide range of deciduous to evergreen host plants dominating in the middle mountain regions by Devkota \& Glatzel (2005), Devkota \& Kunwar (2006a) and Devkota et al. (2010). Distribution of mistletoe has been studied in a wide range of natural plant communities and a comprehensive understanding has been developed about the factors affecting their occurrence and spread (Reid et al., 1995; Overton, 1996; Aukema \& Martinez del Rio, 2002). Mistletoes, typically show distinctly aggregated spatial distributions (Overton, 1994; Devkota \& Glatzel, 2005; Devkota et al., 2010) which are influenced considerably by host distribution and the movement patterns of dispersal vectors (Devkota \& Kunwar, 2006a). A wide variety of habitat, plant species composition and community structure are also believed to influence the behavior of mistletoe vectors (mistletoe birds) which move preferentially among sites with specific ecological characteristics of habitats (Devkota \& Acharya, 1996; Devkota \& Glatzel, 2005; Devkota \& Kunwar, 2006b; Watson, 2001). 
Mistletoes have been the subjects of special interest for a long time due to their fascinating physiology and booming parasitic nature in many parts of the world. Despite their harmful effects on the host plants, mistletoes are considered an important component of plant diversity and forest ecosystems throughout the world. Despite a large number of botanical explorations by Nepalese and botanists from abroad, mistletoes have been understudied in the Nepal Himalayas irrespective of their rich floral diversity. Hara et al. (1982) in their much-elaborated checklist of flowering plants of Nepal has reported 15 species and 1variety of mistletoe from Loranthaceae and Viscaceae families. Such a gap in knowledge may contribute to threatening mistletoe of the country before knowing their diversity and realizing their importance in the Himalayan ecosystem. The primary objective of the study was to study the ecological status of mistletoe of Panchase Protected Forest and people's perception of its conservation.
The study was carried out in Panchase Protected Forest in the Middle Mountain Region of Central Nepal Himalayas. The forest covers area within Annapurna Rural Municipality and Pokhara-Lekhnath Municipality of Kaski District, Kusma Municipality of Syangja district, and Modi Rural Municipality of Parbat district. Panchase Protected Forest was gazette in 2012 by the Government of Nepal and has an area of $57.76 \mathrm{~km}^{2}$ and lies between $28^{\circ} 10^{\prime} 55^{\prime \prime}-28^{\circ} 15^{\prime} 56^{\prime \prime} \mathrm{N}$ and $83^{\circ} 48^{\prime} 03^{\prime \prime}-83^{\circ} 49^{\prime} 53^{\prime \prime} \mathrm{E}$ with an altitudinal variation from $1450 \mathrm{~m}$ to $2517 \mathrm{~m}$ above the mean sea level. It represents an important ecological zone that is less addressed amongst the country's protected area system and is only one biodiversity corridor linkage of lowland (Chitwan-Nawalparasi) and Annapurna Himalaya range (Chitwan-Annapurna Conservation Landscape). The lower belt of the Panchase forest close to the settlement is managed as community forests and the upper belt is government-managed protected forest (Fig. 1)

\section{MATERIALS AND METHODS}

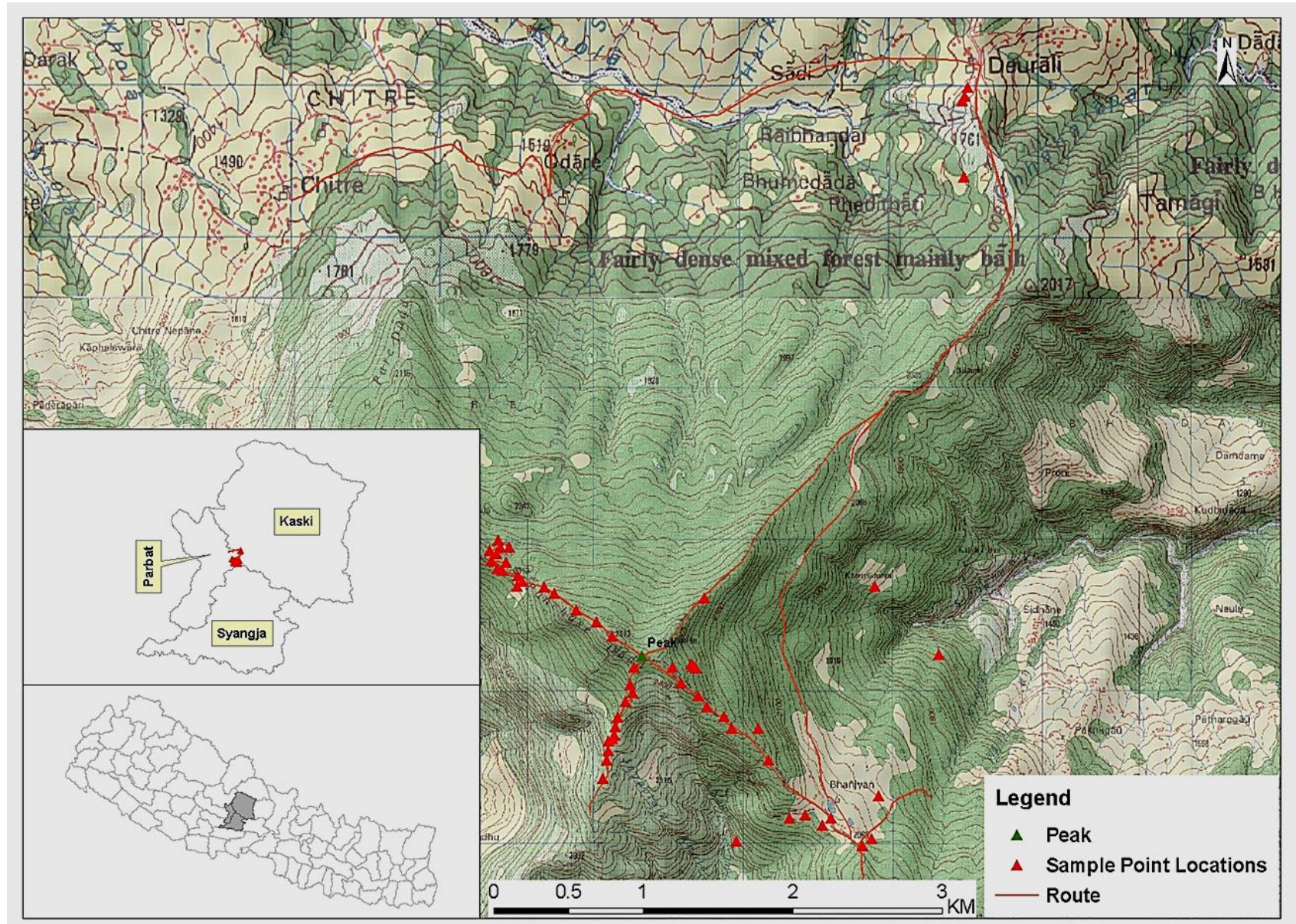

Fig. 1. Map showing study sites in Panchase Protected Forest (Map source: Department of Survey, Government of Nepal; Scale 1:25,000, Contour interval at 200m)

The forest lies in sub-tropical expanding to a temperate region having a typical monsoon climate with a $4055 \mathrm{~mm}$ average annual rainfall and receives occasional snow during winter at a higher elevation. The forest has been 
characterized by lower sub-tropical and upper cool temperate vegetation representing five major forest types; alder forest, chir pine, broad-leaved forest, East Himalayan oak-laurel forest, lower temperate oak forest, and Schima-Castanopsis forest.

A reconnaissance survey (June 2017) was carried out to collect information on forest conditions and to select the possible sites for a detailed study, that was followed by two field visits in October 2017 and April 2018. Considering mistletoe inventory as a challenging task, methods from Muir and Moody (2002) and Hawksworth (1977) were adopted and applied carefully. Inventory was carried out along the forest trails and data were collected using fixed radius $(10 \mathrm{~m})$ plots located $20 \mathrm{~m}$ inside the trail for estimating the incidence (plot infected) and severity (intensity of infection in an individual tree). Detail information on mistletoe and host trees such as species diameter, height, and mistletoe infection severity was estimated by using the mistletoe infection rating system (MIRS) modified from Hawksworth (1977). Collected mistletoe specimens were identified from previously available works of literature whereas; hosts herbariums were prepared following Bridson and Forman (1992). All collected specimens were identified at the National Herbarium and Plant Laboratories, Godawari, Lalitpur, and deposited at the Botany Department, Amrit Campus. The nomenclature of the species was based on the angiospermic phylogenetic group (APG III; Chase \& Reveal, 2009).

A social survey was carried out to understand the local perception using a semi-structured questionnaire, among 50 people of various age groups and occupations, regarding the mistletoe knowledge, uses, and the need of mistletoe conservation. Biodiversity conservation confidence index (BCCI) was used to assess the local perception by converting the qualitative answer into weighted value. Value 1 was assigned for each positive response and value 0 was assigned for each negative response. The diffusion index for each question was calculated by adding the sum of the assigned weighted value (FNCCI, 2012). The results were analyzed and interpreted based on the total score value obtained from the indices, the frequency and percentage of responses of the individual question were calculated. Frequencies of respondents and options for the individual question were calculated using equation (1). Data were analyzed using Microsoft Windows version 10, Excel 2013.

$$
\text { Frequency }=\left(\sum_{n=1}^{N} \mathrm{Pin} / \mathrm{N}\right) * 100
$$

Where, $\mathrm{P}=$ diffusion index for the $\mathrm{i}^{\text {th }}$ question of the $\mathrm{n}^{\text {th }}$ respondent, and $\mathrm{N}=$ total number of respondents.

\section{RESULTS}

A total of seven mistletoe species, six belonging to four genera; Scurrula, Helixanthera, Taxillus, and
Dendrophthoe in the family Loranthaceae and a single genus Viscum in the family Viscaceae were recorded from 27 host species representing 24 genera in 18 families (Table 1). Genus Scurrula was represented with two species elata and parasitica and genus Taxillus with umbellifer and vestitus species. Helixanthera ligustrina, Dendrophthoe pentndra, and Viscum articulatum were only one species in each genus. The Scurrula parasitica and $S$. elata were found infecting a large number of host trees, i.e., 22 and 19, respectively, followed by Taxillus umbellifer (11 hosts) indicating a high degree of a generalist, whereas Taxillus vistitus and Dendrophthoe pentandra were recorded only from two and one host species, respectively (Fig. 2). Among all host species, Litsea cubeba, Alnus nepalensis and Quercus semecarpifolia were found to be highly favored host species infected by five mistletoe species each (Fig. 3).

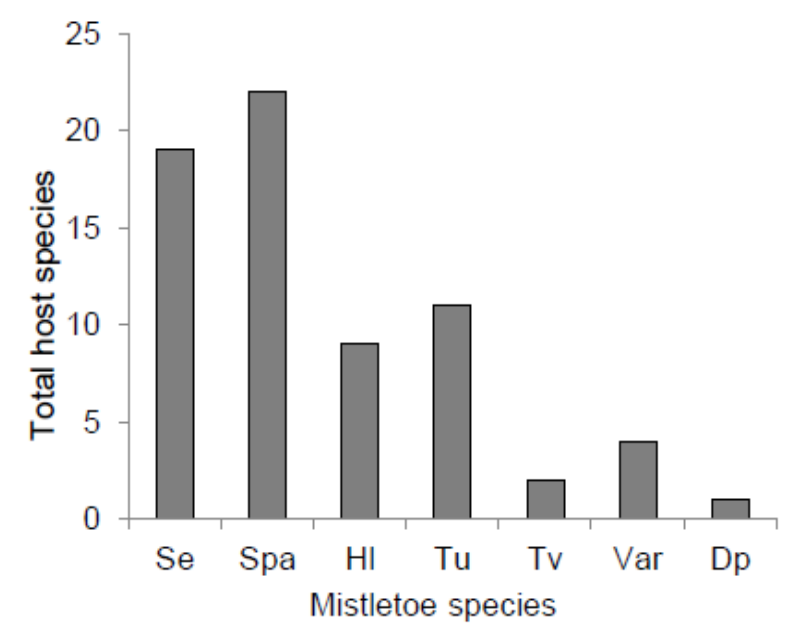

Fig. 2. Number of host species for each mistletoe species (Se: Scurrula elata, Spa: Scurrula parasitica, Hl: Helixanthera ligustrina, Tu: Taxillus umbellifer, Tv: Taxillus vestitus, Var: Viscum articulatum, Dp: Dendrophthoe pentandra)

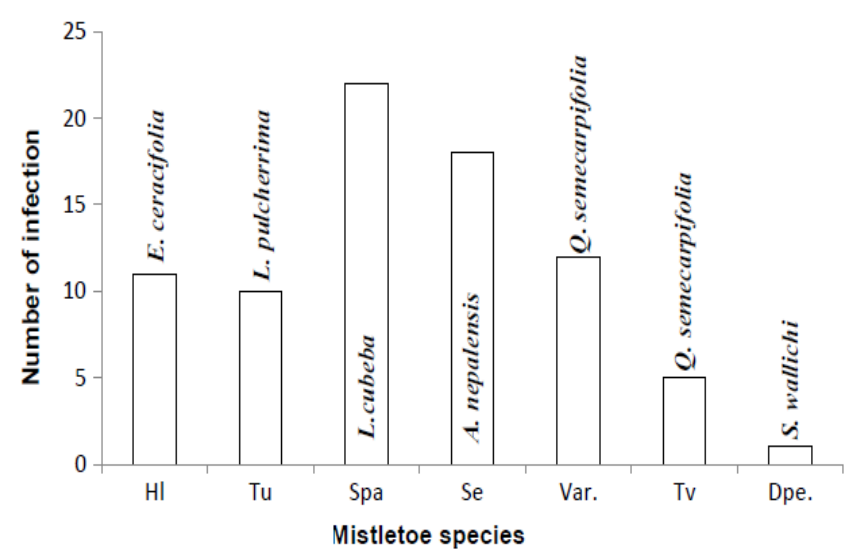

Fig. 3. Highly infected host species with a total number of infection by mistletoe species 
Table 1. Host list of mistletoe species

\begin{tabular}{|c|c|c|c|c|c|c|c|c|c|}
\hline Family & Host species & Se & Spa & HI & Tu & $\mathbf{T v}$ & Var & Dp & No. \\
\hline \multirow[t]{2}{*}{ Adoxaceae } & Viburnum erubescens Wall. Ex Dc. & $*$ & $*$ & & $*$ & & & & 3 \\
\hline & V. mullaha Buch. -Ham. ex D. Don & $*$ & $*$ & & & & & & 2 \\
\hline Aquifoliaceae & Ilex excels (Wall) Hook. Fil. & & & & $*$ & & & & 1 \\
\hline Betulaceae & Alnus nepalensis D. Don & $*$ & $*$ & $*$ & & & & & 3 \\
\hline \multirow[t]{2}{*}{ Ericaceae } & Lyonia ovalifolia (Wall.) Drude & $*$ & $*$ & $*$ & $*$ & & & & 4 \\
\hline & Rhododendron arboreum $\mathrm{Sm}$. & $*$ & $*$ & $*$ & $*$ & & & & 4 \\
\hline Euphorbiaceae & Macaranga indica Weight & $*$ & $*$ & $*$ & & & & & 3 \\
\hline \multirow[t]{3}{*}{ Fagaceae } & Castanopsis indica A. Dc. & $*$ & & & & & & & 1 \\
\hline & Quercus lamellose Sm. & $*$ & $*$ & & & & $*$ & & 3 \\
\hline & Q. semecarpifolia $\mathrm{Sm}$. & $*$ & $*$ & & $*$ & $*$ & $*$ & & 5 \\
\hline \multirow[t]{2}{*}{ Lauraceae } & $\begin{array}{l}\text { Lindera pulcherrima Var pulcherrima } \\
\text { (Nees) Benth. Ex Hook.F. }\end{array}$ & $*$ & $*$ & & * & & & & 3 \\
\hline & Litsea cubeba Pers. & $*$ & $*$ & & $*$ & $*$ & $*$ & & 5 \\
\hline Moraceae & Ficus thonningii Blume & & $*$ & & & & & & 1 \\
\hline Myricaceae & $\begin{array}{l}\text { Morella esculenta (Bunch. -Ham. Ex D. Don) } \\
\text { I. M. Turner }\end{array}$ & $*$ & 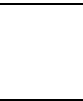 & & & & & & 1 \\
\hline \multirow{2}{*}{$\begin{array}{l}\text { Pentaphylacacea } \\
\text { e }\end{array}$} & Eurya acuminata Dc. & $*$ & $*$ & $*$ & & & & & 3 \\
\hline & E. cerasifolia (D. Don) Kobuski & $*$ & $*$ & $*$ & $*$ & & & & 4 \\
\hline Primulaceae & Maesa chisia D. Don & & $*$ & $*$ & & & & & 2 \\
\hline \multirow[t]{4}{*}{ Rosaceae } & Prunus cornuta (Wall. Ex Royle) Steud & & & & $*$ & & & & 1 \\
\hline & Pyrus pashia Buch.-Ham. Ex D. Don & & $*$ & & & & & & 1 \\
\hline & Rosa brunonii Lindl & $*$ & $*$ & $*$ & & & $*$ & & 4 \\
\hline & Rubus niveus Thunb. & $*$ & $*$ & & & & & & 2 \\
\hline Rubiaceae & $\begin{array}{l}\text { Himalrandia tetrasperma (wall. ex Roxb.) } \\
\text { T. Yamaz. }\end{array}$ & & * & & & & & & 1 \\
\hline Rutaceae & Zanthoxyllum acanthopodium Dc. & $*$ & $*$ & & & & & & 2 \\
\hline Siamroubaceae & Brucea javanica Merrr. & $*$ & $*$ & & $*$ & & & & 3 \\
\hline Symplocaceae & Symplocos ramosissima Wall. & $*$ & $*$ & $*$ & $*$ & & & & 4 \\
\hline Theaceae & Schima wallichii (Dc.) Korth. & & & & & & & $*$ & 1 \\
\hline Thymelaeaceae & Daphne papyracea Wall. ex G. Don & & $*$ & & & & & & 1 \\
\hline Total number & 27 & 19 & 22 & 9 & 11 & 2 & 4 & 1 & \\
\hline
\end{tabular}

(Se: Scurrula elata, Spa: Scurrula parasitica, H1: Helixanthera ligustrina, Tu: Taxillus umbellifer, Tv: Taxillus vestitus, Var: Viscum articulatum, Dp: Dendrophthoe pentandra)

All mistletoe species were recorded between the elevational ranges of $1605 \mathrm{~m}$ to $2476 \mathrm{~m}$ but individual mistletoe species showed irregular and aggraded distribution patterns along the elevation gradient. Scurrula parasitica, S. elata and Helixanthera ligustrina in the family Loranthaceae showed a much wider elevational distribution pattern compared to other species (Fig. 4). Genus Scurulla was recorded showed widest distribution pattern between $1610 \mathrm{~m}$ and $2475 \mathrm{~m}$ whereas; Dendropthoe pentendra had the narrowest distribution. Viscum articulatum, Taxillus vistitus, and Taxillus umbellifer were recorded only at the higher elevational range between $2135 \mathrm{~m}$ and $2405 \mathrm{~m}$. Only $16 \%$ of respondents, elderly members of users' group, were found aware of the conservation of mistletoes and $46 \%$ of respondents possessed very little knowledge regarding 
mistletoe as they could simply recognize them on host trees. However, $38 \%$ of respondents (elderly farmers or herders) knew some uses of mistletoes (Fig. 5).

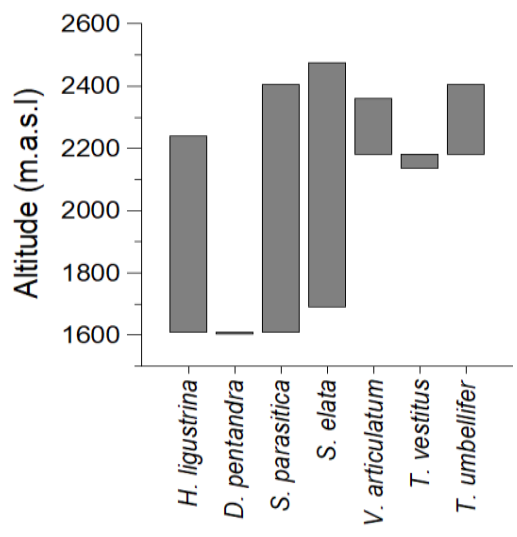

Fig. 4. Elevation wise distribution pattern of mistletoe species

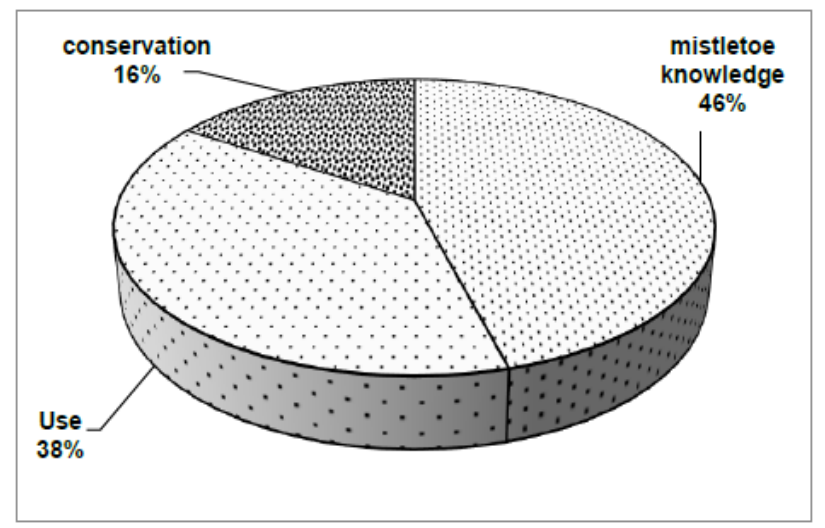

\section{Fig. 5. Peoples' knowledge of mistletoe}

Elderly farmers were found to possess more knowledge and familiar with mistletoe $(68 \%)$ whereas, businessmen/teachers had little knowledge $(23 \%)$ and the local students were the least $(9 \%)$ when $46 \%$ mistletoe knowledge category was divided into three categories (Fig. 6).

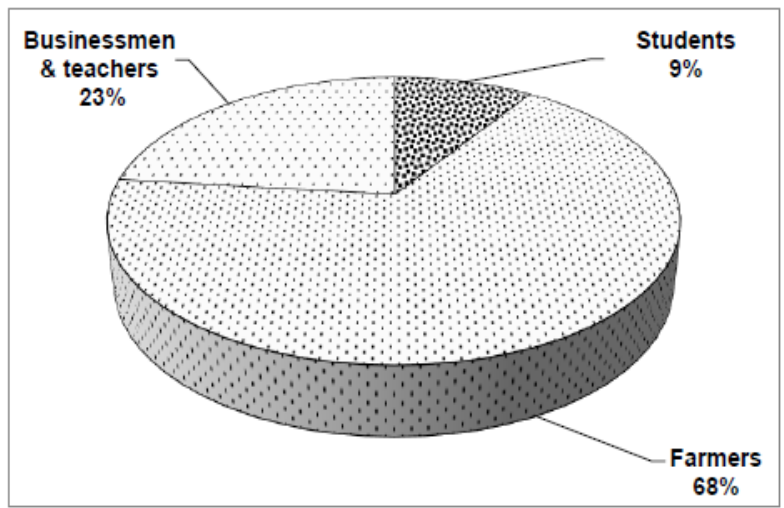

Fig. 6. Familiarization and knowledge of mistletoe
Regarding the knowledge of uses of mistletoe $78 \%$, respondents possessed the knowledge of the fodder value of mistletoe. Similarly, $16 \%$ of respondents as food value, while only $4 \%$ of respondents as medicinal value. Whereas, $2 \%$ of respondents possessed the knowledge as its use for trapping birds and mouse by the local people (Fig. 7).

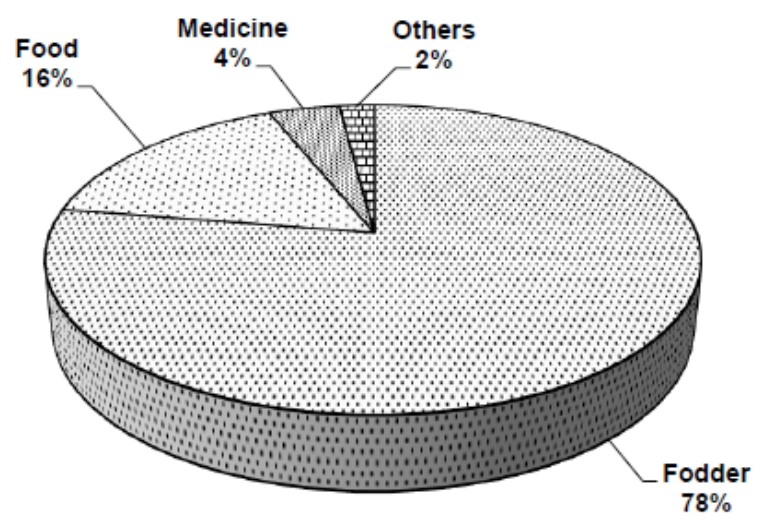

Fig. 7. Knowledge of mistletoe use

Regarding the conservation of mistletoe, farmers (68\%) recognized the need for conservation of mistletoes that was followed by businessman/teachers (32 \%). But surprisingly no students were unaware of the need for mistletoe conservation (Fig. 8). Farmers demanded the conservation of mistletoes as they are important sources of food for animals and fodder.

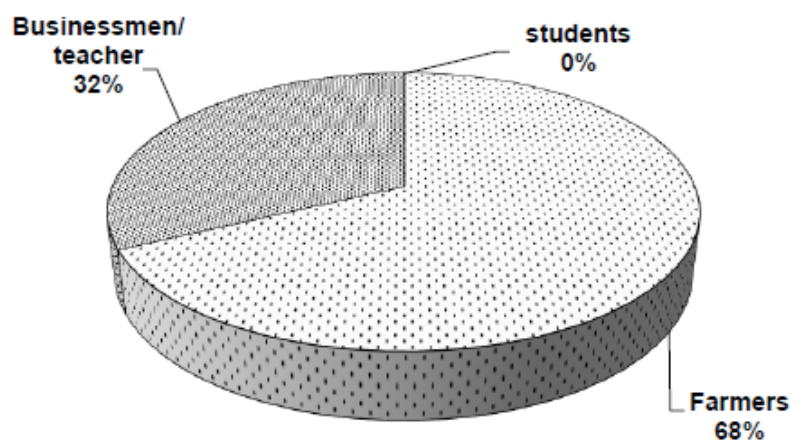

Fig. 8. Conservation perceptions of locals

\section{DISCUSSION}

Panchase Protected Forest, despite its smaller size, showed a similar pattern of mistletoe diversity having seven mistletoe species, six belonging to four genera in the family Loranthaceae, and one species belonging to one genus in the family Viscaceae. Similar to the previous studies carried out by Devkota and Glatzel (2005), Devkota and Kunwar (2006a), Devkota et al. (2010) in other parts of the country, the mistletoes of Panchase Forest shared the similar pattern of host diversity like in other parts of Nepal as reported earlier by Devkota and Glatzel (2005) in Annapurna Conservation Area, Devkota 
and Kunwar (2006b) in Phulchowki Area, and Devkota et al. (2010) in Langtang National Park and ShivapuriNagarjun National Park.

Out of the total recorded 27 host trees, the occurrence of Scurrula parasitica on 22 hosts and S. elata on 19 hosts had the highest number of hosts in Loranthaceae showing a generalist pattern of infecting a wide range of host trees with family Rosaceae having the largest number of hosts, a pattern consistent with Barlow (1991) and previous studies carried out in Nepal by Devkota (2003), Devkota and Acharya (1996), Devkota and Glatzel (2005), Devkota and Kunwar (2006b) and Devkota et al. (2010). The occurrence of mistletoes on a large number of host species is a generalist pattern which is considered to be due to the high species diversity of plant communities with few dominant species (Okubamichael et al. 2016) thus generalists mistletoe species are often composed of distinct host-species population. Whereas, the stability of host availability through time and space is the dominant factor in determining the host specificity in the case of New Zealand mistletoes (Norton \& Lange, 1999). Mistletoes of Panchase forest have also followed the same pattern of generalist and specialist. The occurrence of Scurrula parasitica, S. elata, and Helixanthera ligustrina on a wide range of hosts and over a wider elevational range is due to the ability to infest the commonly occurring host species whereas, the others have shown a general pattern of specificity with narrow elevational range.

Panchase forest is no exception in showing the similar elevation distribution pattern of mistletoes in Nepal. Elevational distribution of mistletoes also shared a similar pattern that was governed by microclimatic factors like temperature, sunlight, moisture, and aspects, consistent with that of Devkota and Glatzel (2005), Devkota and Kunwar (2006b) and Devkota et al. (2010). The occurrence of genera Taxillus and Viscum at higher elevation also followed the same pattern and was determined by the occurrence of their respective host species at a higher elevation as observed by Griffiths et al. (2016). The common occurrence of mistletoes in marginal forests, roadsides, partially disturbed habitats, along the forest trails and open forest habitats in the Panchase area showed consistency with the finding of Ganguly and Kumar (1976), Lopez et al. (2002) and Devkota and Glatzel (2005). Generalist mistletoe species of Loranthaceae showed a common pattern of occurrence over a wide range of host species despite elevation whereas, Viscaceae mistletoe being host specialist was unable to infest a wide range of host was recorded from a very narrow elevation range.

Rich and diverse types of indigenous, traditional, and local forest and pasture management practices are found throughout Nepal according to different cultures, locations, climatic conditions, and socio-economic situations that are practiced for centuries by rural communities (Karki \& Adhikari, 2015). Despite the ecological role of mistletoes in natural plant communities they have always been overlooked by conservationists and have undervalued ethnobotanical importance due to their parasitic nature and associated disliked folklores with them. Local communities in and around the Panchase area, which is rich in providing ecosystem services (Bhandari et al., 2018), have a mixed knowledge of mistletoe as in the other parts of the Annapurna Conservation Area (Devkota, 2003). Older generation people of the Panchase area are familiar and possess knowledge of mistletoes but only a few of them were aware of their uses and conservation values compared to the younger generation who possess poor knowledge of mistletoes. The knowledge of uses of mistletoe as fodder (goats and buffaloes) is limited to elderly people having domesticated animals and frequently forest visitors to collect fodder, firewood, and other edible products. Unlike other parts of Nepal as described by Tamang and Singh (2014), mistletoes of Panchase forest are less exploited in traditional medical practices by the rural communities.

There is an amazing gap in inheriting the plant resources use knowledge from the older generation to the younger generation in the local communities of the Panchase area similar to the observation of $\mathrm{O}^{\prime}$ Neill and Rana (2016) in other parts of Nepal Himalayas. Other possible reasons could be the out-migration of local families to cities for better life and education, dependency on modern health facilities, and involvement in the tourism business. Lack of knowledge and values of mistletoes in natural plant communities among the younger generation of local communities are similar to the results of Shrestha (2016) while studying the values of sacred groves of the Kathmandu Valley. Such findings concerning the declining ethnobotanical knowledge in the local communities are rapidly eroding from the local mountainous communities of the Panchase area showing consistency with O'Neill and Rana (2016), and Rana and Rana (2016) results on parasitic plants in other regions of Nepal.

\section{CONCLUSION}

Panchase Protected Forest is composed of considerable mistletoe species diversity as in other parts of Nepal showing consistency in their distribution pattern and have a similar nature of spreading over a wide range of host species, although some of them are host specific. Their distribution pattern is affected by host species distribution as the climatic condition changes with ecological set up that change with elevation as indicated by previous studies. Compared to earlier studies Analogous to other parts of the country, very few ethnic groups of rural 
mountain communities possess very little knowledge regarding their medicinal uses except their limited fodder use. Diminishing knowledge regarding the ethnobotanical indigenous knowledge of plant resources of a biodiversity-rich country and lack of efficient conservation knowledge and practices in the local communities is leading towards the loss of valuable plant resources of the country. Being a protected forest more conservation initiatives, including the awareness program, should be undertaken by the government through the stakeholder involvement to protect biodiversity.

\section{ACKNOWLEDGMENT}

We are thankful to the Nepal Academy for Science and Technology for financial support to conduct the study.

\section{REFERENCES}

Aukema, J. E. (2003). Vectors, viscin, and viscaceae: Mistletoes as parasites, mutualists, and resources. Frontiers in Ecology and the Environment, 1(4), 212-219.

Aukema, J. E., \& Martinez del Rio, C. (2002). Variation in mistletoe seed deposition: Effects of intra- and interspecific host characteristics. Ecography, 25, 139-144.

Barlow, B. A. (1991). Conspectus of the genera Scurrula L. and Taxillus tieghem (Loranthaceae) in the malesian region. Blumea-Biodiversity, Evolution, and Biogeography of Plants 36(1), 63-85.

Bhandari, A. R., Khadka, U. R., \& Kanel K. R. (2018). Ecosystem services in the mid-hills forests of western Nepal: a case of Panchase Protected Forest. Journal of Institute of Science and Technology, 23, 10-17.

Bridson, D., \& Forman, L. (1992). The Herbarium handbook. $2^{\text {nd }}$ ed. Royal Botanic Garden, Kew.

Chase, M. W., \& Reveal, J. L. (2009). A phylogenetic classification of the land plants to accompany APG III. Botanical Journal of the Linnean Society, 161(2), 122-127.

Devkota, M. P., \& Acharya, N. (1996). Mistletoes (Loranthaceae \& Viscaceae) in the Kathmandu valley, Nepal: Altitudinal distribution, host trees, pollinators and seed dispersers. Acta Phytotaxonomy Geobotany, 47(2), 213-219.

Devkota, M. P., \& Glatzel, G. (2005). Mistletoes of Annapurna conservation area, central Nepal Himalayas. Journal of Japanese Botany, 80(1), 2736.

Devkota, M. P., \& Kunwar, R. M. (2006a). Diversity, distribution and host range of mistletoes in
Godawari-Phulchowki area, Kathmandu Nepal. Journal of Japanese Botany, 81, 255-261.

Devkota, M. P., \& Kunwar, R. M. (2006b). Pollination and dispersal of three Scurrula species (Loranthaceae) in the Godawari area of Kathmandu valley, Nepal. Indian Journal of Botanical Research, 2(2), 115-128.

Devkota, M. P. (2003). Mistletoes of the Annapurna conservation area of the central Nepal Himalayas: Diversity, distribution and biology (PhD Thesis). Institute of Forest Ecology, University of Natural Resources and Life Sciences (UNI BOKU), Vienna, Austria.

Devkota, M. P., Joshi, G., \& Parajuli, P. (2010). Diversity, distribution, and host range of mistletoe in protected and unprotected areas of Central Nepal Himalayas. Banko Janakari, 20(2), 14- 20.

FNCCI. (2012). A report on the FNCCI Business Confidence Survey. Federation of Nepalese Chamber of Commerce and Industry, Kathmandu, Nepal, p 20.

Ganguly, P., \& Kumar, N. C. (1976). Topographical distribution of the phanerogamic parasites in Sukna forest, Darjeeling District, West Bangal. Indian Forester, 102, 459-462.

Griffiths, M. E., Ruiz, N., \& Ward, D. (2016). Mistletoe species richness patterns are influenced by host geographic range rather than Nitrogen content. African Journal of Ecology, 55(1), 101-110.

Hara, H., Charter, A. O., \& Williams, L. H. J. (1982). An enumeration of flowering plants of Nepal. Vol. III. British Museum (Natural History), London.

Hawksworth, F. G. (1977). The 6-Class Dwarf Mistletoe Rating System. USDA forest service, Rocky mountain forest and Range Experiment Station, General Technical report. RM-48, $\mathrm{p} 7$.

Karki, M., \& Adhikari, J. R. (2015). Integrating indigenous, local and modern knowledge for sustainable conservation and management of forest ecosystems in Nepal. DOI: 10.13140/RG.2.1.5023.9206.

Kuijt, J. (1969). The biology of parasitic flowering plants. Berkeley, California: University of California Press, p. 246.

Lopez, De B. L., Ornelas, J.F., \& García-Franco, J. G. (2002). Mistletoe infection of trees located at fragmented forest edges in the cloud forests of central Veracruz, Mexico. Forest Ecology and Management, 164(1-3), 293-302.

Mallams, K. M., \& Mathiasen, R. L. (2010). Mistletoes on hardwoods in the United States. Forest insect \& 
Ecological status and peoples' perception of mistletoes in Panchase protected forest, central Nepal Himalayas

disease leaflet 147. USDA Forest Service, Pacific Northwest Region, Portland, Oregon.

Mathiasen, R., Nickrent, D. L., Shaw, D.C., \& Watson, D.M. (2008). Mistletoes: pathology, systematics, ecology, and management. Plant Disease, 92, 9881004.

Muir, J. A., \& Moody, B. (2002). Dwarf mistletoe surveys. USDA Forest Service General Technical Report, RMRS-GTR, 98, 67-73.

Nickrent, D. L. (1997 onwards). The Parasitic Plant Connection. [www.parasiticplants.siu.edu/] accessed on Feb 15, 2020.

Nickrent, D. L. (2011). Sanatalales (Including Mistletoes). In: Encyclopedia of Life Sciences (ELS). Chichester: John Wiley \& Sons, Ltd...

Norton, D. A., \& de Lange, P. J. (1999). Host specificity in parasitic mistletoes (Loranthaceae) in New Zealand. Functional Ecology, 13, 552-559.

O'Neill, A. R., \& Rana, S. K. (2016). An ethnobotanical analysis of parasitic plants (Parjibi) in the Nepal Himalayas. Journal of Ethnobiology and Ethnomedicine, 12, 14.

Okubamichael, D. Y., Griffiths, M. E., \& Ward, D. (2016). Host specificity in parasitic plantsperspectives from mistletoes. AoB Plants. 8, plw069; doi: 10.1093/aobpla/plw069.

Overton, J. M. (1994). Dispersal and infection in mistletoe metapopulations. Journal of Ecology, 82, 711-723.
Overton, J. M. (1996). Spatial autocorrelation and dispersal in mistletoes: Field and simulation results. Vegetatio, 125, 83-98.

Rana, S. K., \& Rana, H. K. (2016). Peoples' perceptions of parasitic plants: helping humans, harming plants? International Journal of Biological Research, 4(2), 215-219.

Reid, N., Smith, M. S., \& Yan, Z. (1995). Forest canopies. In M. D. Lowman, and N. M. Nadkarni (Eds), Ecology and population biology of mistletoes, ( $\mathrm{p}$. 285-310). San Diego/California: Academic Press.

Shaw, D. C., Watson, D. M., \& Mathiasen, R. L. (2004). Comparison of dwarf mistletoes (Arceuthobium spp., Viscaceae) in the western United States with mistletoes (Amyema spp., Loranthaceae) in Australia-ecological analogs and reciprocal models for ecosystem management. Australian Journal of Botany, 52, 481-498.

Shrestha, L. J. (2016). Role of sacred groves in tree diversity conservation in Kathmandu valley $(\mathrm{PhD}$ thesis). Tribhuvan University, Kathmandu, Nepal.

Tamang, P., \& Singh, N. (2015). Medical Ethnobiology and Indigenous Knowledge System of the Lapcha of Fikkal VDC of Ilam, Nepal. Journal of Institute of Science and Technology, 19(2), 45-52.

Watson, D. M. (2001). Mistletoe: a keystone resource in forests and woodlands worldwide. Annual Review of Ecology and Systematics, 32, 219-249. 